\title{
PENGARUH PEMBERIAN TIMBAL (Pb) DOSIS KRONIS SECARA ORAL TERHADAP PENINGKATAN PENANDA KERUSAKAN ORGAN PADA MENCIT
}

\author{
Abdul Malik Setiawan \\ Jurusan Biologi Fakultas Sains dan teknologi UIN Malang \\ Email : abdul_malik_setiawan@yahoo.com
}

\begin{abstract}
Several kind of heavy metals that present in the environment are considered as toxic substance to human and animal. Lead $(\mathrm{Pb})$ is one of heavy metals that increase in use for the last decade. Lead toxicity to human had wide influence in medical aspect, from nerve problem, bone metabolics disturbance until liver and renal failure. This experiment tried to found out the effect of cronic oral lead consupmtion to lead plasma rate in mice. Design of this experiment is true research experiment to test wheater there is an effect of oral lead consumption to acumulation of lead in blood plasma of mice. The dose devided to two kinds, medium dose (50 ppm) and high dose (100 ppm). The results show increase of lead accumulation in blood plasma of the mice compared to control group.

Key word : Lead, accumulation, toxicity, blood pasma, mice
\end{abstract}

\section{Pendahuluan}

Berbagai macam logam yang terdapat pada lingkungan merupakan zat yang sangat toksik pada manusia dan hewan. Logam-logam tersebut seperti timbal, merkuri dan arsen yang memiliki sifat tosik telah bertahun-tahun diketahui oleh manusia. Kemampuannya berakumulasi pada lingkungan sehingga masuk pada rantai makanan membuatnya menjadi semakin berbahaya terhadap kesehatan. Selain pada rantai makanan, penyebaran logam berat pada ekosistem berasal dari pengguanaannya yang cukup besar pada industri modern sehingga dapat ditemukan pada air, udara bahkan alat-alat perkantoran. (Barbossa, 2005)

Pencemaran logam berat di Indonesia, cenderung meningkat sejalan dengan meningkatnya proses industrialisasi, terutama di kota-kota besar seperti jakarta dan surabaya. Masyarakat di perkotaan memiliki resiko pencemaran yang lebih tinggi, khususnya di daerah dengan lalu lintas yang padat.(Chahaya,2005) Meningkatnya jumlah kendaraan bermotor serta tingkat kemacetan memberikan kemungkinan peningkatan polusi yang tersebar di kota Malang. Para peneliti telah beberapa kali melakukan penelitian tentang kadar pencemaran timbal/Pb di Indonesia. (Browne,1999) Hasil yang didapatkan menunjukkan bahwa terdapat peningkatan kadar timbal/Pb di dalam darah terutama pada anakanak dan pekerja di jalan raya.(Heinze, 1998. Albalak, 2003)
Timbal $(\mathrm{Pb})$ adalah salah satu jenis logam berat yang mengalami peningkatan penggunaan pada industri akhir-akhir ini. Timbal berasal dari kerak bumi, karena proses alam dan penambangan menyebabkan timbal dapat dijumpai pada ekosistem makhluk hidup. Logam timbal banyak digunakan pada kehidupan seharihari, dari kosmetik sampai bahan bakar kendaraan bermotor. (Kurniawan, 2008) Jalur masuknya timbal ke dalam tubuh manusia dapat melalui saluran pencernaan lewat makanan dan minuman, hirupan asap kendaraan bermotor serta hasil industri dan melalui penyerapan dikulit dari kosmetik atau mainan. (Sakkir, 2008)

Toksisitas timbal pada kesehatan manusia mempunyai pengaruh yang luas, dari gangguan syaraf, gangguan metabolisme tulang sampai kerusakan ginjal dan gangguan fungsi hati.(sakkir, 2008) Bahkan penelitian terakhir menunjukkan bahwa logam timbal memiliki sifat karsinogenik yang dapat merangsang terjadinya kanker pada manusia. Organ-organ tubuh yang menjadi tempat akumulasi timbal adalah liver, ginjal dan otak. Anak-anak dan balita memiliki resiko yang lebih tinggi terkena pencemaran bahan-bahan toksik. Jika dilihat dari rasio berat badan, balita dan anak-anak mengkonsumsi makanan dan minuman serta menghirup udara lebih banyak daripada orang dewasa. Paparan dalam waktu yang lama terhadap bahan toksis pada anak-anak menyebabkan penurunan Kecerdasan (IQ), kemampuan membaca dan gangguan perilaku yang menetap. Hal ini 
disebabkan karena masih terjadi pertumbuhan pada sistem syaraf anak-anak

Toksisitas logam berat pada pada manusia berkaitan erat dengan akumulasinya pada jaringan sehingga menyebabkan gangguan proses fisiologis baik secara langsung maupun tidak langsung di tingkat molekuler. Timbal memiliki kemampuan untuk menimbulkan kerusakan oksidatif pada jaringan dan meningkatkan peroksidasi lemak, kerusakan DNA serta meningkatkan produksi ROS (Reactive Oxygen Species).(Komousani, 2011) Logam-logam yang bersifat toksik meningkatkan produksi dari radikal bebas. Proses terjadinya kerusakan akibat timbal disebabkan berbagai faktor. Timbal secara langsung dapat menghambat kerja enzim, kemudian timbal juga dapat menghambat penyerapan mineral oleh tubuh.(Yushui, 2012) Selain itu timbal juga dapat menurunkan kadar antioksidan dan meningkatkan produksi radikal bebas. Ketidakseimbangan antara serangan oksidan dan pertahanan antioksidan pada jaringan dan sel mengarah pada terjadinya kerusakan organ. (Wang Lin, 2010)

Penelitian mengenai pengaruh toksisitas konsumsi timbal bertujuan untuk mengetahui dampak toksik pada mahkluk hidup terutama manusia. Jika manusia terpapar logam timbal dalam waktu yang lama maka akan terjadi akumulasi di berbagai organ. Toksisitas timbal dalam organ dapat menyebabkan gangguan fungsi organ yang pada akhirnya akan menyebabkan berbagai penyakit. Penelitian ini mencoba mengukur kadar $\mathrm{Pb}$ dalam darah yang merupakan penanda terjadinya akumulasi zat $\mathrm{Pb}$ di dalam tubuh makhluk hidup.

\section{Metode Penelitian}

\section{Desain penelitian}

Penelitian ini adalah penelitian eksperimental murni untuk menguji pengaruh pemberian timbal $(\mathrm{Pb})$ dosis kronis secara oral terhadap peningkatan kadar plasma $\mathrm{Pb}$ pada mencit. Hewan coba dikelompokkan dalam 3 kelompok perlakuan, sebagai berikut :

1. Kelompok $1:$ air bersih

2. Kelompok $2:$ air bersih $+\mathrm{Pb}$ acetat $50 \mathrm{ppm}$ selama 10 minggu

3. Kelompok 3: air bersih $+\mathrm{Pb}$ acetat 100 ppm selama 10 minggu

Masing-masing kelompok perlakuan terdiri dari 4 hewan coba. Parameter yang diukur adalah kadar zat $\mathrm{Pb}$ di dalam plasma darah mencit.

\section{Alat dan bahan percobaan}

Penelitian ini menggunakan mencit dengan kondisi sehat, berusia 2 bulan, berat badan 15-20 gram dengan jenis kelamin jantan. Sebelum percobaan, mencit diletakkan pada ruangan percobaan selama satu minggu untuk beradaptasi. Kandang yang digunakan berupa kandang polypropylene yang berisi sekam dan terdapat botol air minum dengan corong berpengaman yang diletakkan terbalik. Makanan yang diberikan adalah makanan mencit berupa konsentrat $\mathrm{Br} 1$ yang terbuat dari katul dan jagung. Kondisi ruangan percobaan diatur dengan temperatur dan kelembapan yang konstan. Siklus cahaya yang diberikan, seimbang antara 12 jam terang : 12 jam gelap. Selama percobaan mencit diberikan makanan berupa Konsentrat $\mathrm{Br} 1$ dan akses tidak terbatas pada air minum. Preparat Merkuri Khlorida yang diberikan pada hewan percobaan didapatkan dari CV Panadia. Mencit diperoleh dari Laboratorium Fisiologi Hewan Jurusan Biologi Fakultas Sains dan Teknologi UIN Malik Ibrahim Malang. Pengukuran berat badan mencit menggunakan timbangan khusus hewan percobaan (digital analityc cookmaster CMK5055). Penentuan kadar zat $\mathrm{Pb}$ di dalam plasma darah mencit diukur menggunakan metode AAS.

\section{Pemberian Preparat $\mathbf{P b}$}

Mencit di bagi menjadi 3 group. Group I $(n=4)$, mencit yang digunakan sebagai kontrol mendapatkan minuman air bersih tanpa pemberian $\mathrm{Pb}$ acetat. Group II $(\mathrm{n}=4)$ mendapatkan pemberian $\mathrm{Pb}$ acetat dengan dosis 50 ppm selama 10 minggu. Group III mendapatkan pemberian $\mathrm{Pb}$ acetat dengan dosis 100 ppm selama 10 minggu.

\section{Pemerikasaan Analisa Darah}

Setelah perlakuan selama 10 minggu, mencit kemudian dibius sampai kesadarannya menurun. Setelah itu dilakukan pengambilan darah dengan mengorbankan mencit percobaan. Darah diambil sebesar 1-2 $\mathrm{ml}$ kemudian dipindahkan menuju tabung berisi EDTA. Setelah itu plasma darah dipisahkan dari sel darah dengan cara disentrifugasi dengan kecepatan $5000 \mathrm{rpm}$. Plasma darah yang telah 
terpisah dengan supernatan, digunakan untuk menguji kadar $\mathrm{Pb}$ dalam darah dengan menggunakan metode AAS

\section{Analisa Data}

Seluruh teknis pengolahan data dianalisis secara komputerisasi menggunakan Software SPSS 13. dengan taraf signifikan $(\mathrm{P}<0,05)$. Untuk membuktikan pengaruh perlakuan terhadap parameter kadar zat $\mathrm{Pb}$ di plasma darah dilakukan uji regresi, sedangkan untuk membuktikan adanya perbedaan antara kelompok kontrol dan perlakuan dilakukan menggunakan uji Anova satu arah (Anova), kemudian dilakukan uji signifikansi dengan t-test.

\section{Hasil dan Pembahasan}

Kadar zat PB plasma darah pada kelompok percobaan dihitung menggunakan spektrofotometer dengan metode AAS. Terjadi perbedaan diantara kelompok hewan coba. Hasil perhitungan sebagai berikut :

\begin{tabular}{|c|c|c|}
\hline No & $\begin{array}{c}\text { Dosis Perlakuan } \\
\text { Kelompok Hewan Coba }\end{array}$ & $\begin{array}{c}\text { Kadar Pb } \\
\text { Plasma } \\
\text { (mg/L) }\end{array}$ \\
\hline 1 & Mencit $_{1}+$ air bersih & 0.09 \\
\hline 2 & $\mathrm{Mencit}_{2}+$ air bersih & 0.10 \\
\hline 3 & Mencit $_{3}+$ air bersih & 0.11 \\
\hline 4 & $\mathrm{Mencit}_{4}+$ air bersih & 0.10 \\
\hline 5 & $\begin{array}{l}\text { Mencit }_{1}+\text { air bersih }+\mathrm{Pb} \\
\text { acetate } 50 \mathrm{ppm}\end{array}$ & 0.11 \\
\hline 6 & $\begin{array}{l}\text { Mencit }_{2}+\text { air bersih }+\mathrm{Pb} \\
\text { acetate } 50 \mathrm{ppm}\end{array}$ & 0.10 \\
\hline 7 & $\begin{array}{l}\text { Mencit }_{3}+\text { air bersih }+\mathrm{Pb} \\
\text { acetate } 50 \mathrm{ppm}\end{array}$ & 0.11 \\
\hline 8 & $\begin{array}{l}\text { Mencit }_{4}+\text { air bersih }+\mathrm{Pb} \\
\text { acetate } 50 \mathrm{ppm}\end{array}$ & 0.11 \\
\hline 9 & $\begin{array}{l}\text { Mencit }_{1}+\text { air bersih }+\mathrm{Pb} \\
\text { acetate } 100 \mathrm{ppm}\end{array}$ & 0.12 \\
\hline 10 & $\begin{array}{l}\text { Mencit }_{2}+\text { air bersih }+\mathrm{Pb} \\
\text { acetate } 100 \mathrm{ppm}\end{array}$ & 0.13 \\
\hline 11 & $\begin{array}{l}\text { Mencit }_{3}+\text { air bersih }+\mathrm{Pb} \\
\text { acetate } 100 \mathrm{ppm}\end{array}$ & 0.13 \\
\hline 12 & $\begin{array}{l}\text { Mencit }_{4}+\text { air bersih }+\mathrm{Pb} \\
\text { acetate } 100 \mathrm{ppm}\end{array}$ & 0.14 \\
\hline & $\begin{array}{l}\text { Kelompok hewan coba } \\
\text { dan minum yang cuku }\end{array}$ & $\begin{array}{r}\text { mendapatkan } \\
0 \quad \text { selama } \quad 10 \\
\end{array}$ \\
\hline
\end{tabular}

minggu. Kelompok kontrol mendapatkan air minum yang diperoleh dari air kran yang mengalir di laboratorium fisiologi hewan UIN Maliki Malang. Sedangkan kelompok hewan coba mendapatkan air minum yang berasal dari air keran yang sama tetapi ditambahkan $\mathrm{Pb}$ acetate dengan konsentrasi sesuai dengan yang telah ditentukan.

Hasil analisa data menunjukkan korelasi yang sangat kuat antara besarnya dosis perlakuan dengan jumlah kadar $\mathrm{Pb}$ di dalam plasma mencit. Pada pengujian korelasi pearson didapatkan nilai +0.86154979 membuktikan bahwa peningkatan jumlah dosis $\mathrm{Pb}$ yang dikonsumsi oleh mencit berhubungan secara nyata dengan jumlah akumulasi zat $\mathrm{Pb}$ di dalam plasma darah mencit.

\begin{tabular}{lcc}
\hline & $\begin{array}{c}\text { Dosis } \\
\text { Perlakuan }\end{array}$ & $\begin{array}{c}\text { Kadar Pb } \\
\text { plasma }\end{array}$ \\
\hline $\begin{array}{l}\text { Dosis } \\
\text { Perlakuan }\end{array}$ & 1 & \\
\hline $\begin{array}{l}\text { Kadar Pb } \\
\text { plasma }\end{array}$ & 0.86154979 & \\
\hline
\end{tabular}

Tabel 1 : Uji Korelasi dosis perlakuan dengan kadar zat $\mathrm{Pb}$ di plasma darah mencit

Pada uji regresi didapatkan nilai $\mathrm{R}$ sebesar 0.8615 menunjukkan hubungan yang sangat erat antara jumlah dosis perlakuan dengan jumlah akumulasi zat $\mathrm{Pb}$ di dalam plasma darah.

\begin{tabular}{lr}
\hline \multicolumn{2}{c}{ Regression Statistics } \\
\hline Multiple R & 0.86154979 \\
\hline R Square & 0.742268041 \\
\hline Adjusted R Square & 0.716494845 \\
\hline Standard Error & 22.70383046 \\
\hline Observations & 12 \\
\hline
\end{tabular}

Tabel 2 : Uji Regresi dosis perlakuan dengan kadar zat $\mathrm{Pb}$ di plasma darah mencit

Hubungan yang sangat erat memiliki arti semakin tinggi dosis zat $\mathrm{Pb}$ yang terkandung dalam air minum mencit maka semakin tinggi pula akumulasi zat $\mathrm{Pb}$ di dalam plasma darah mencit.

\begin{tabular}{lllllll}
\hline ANOVA & & & & & & \\
\hline $\begin{array}{l}\text { Source of } \\
\text { Variation }\end{array}$ & $S S$ & $d f$ & $M S$ & $F$ & $P$-value & $F$ crit \\
\hline
\end{tabular}




\begin{tabular}{lrrrrrr}
\hline $\begin{array}{l}\text { Between } \\
\text { Groups }\end{array}$ & 14932.58 & 1 & 14932.57594 & 16.4258315 & 0.000530178 & 4.300949462 \\
\hline $\begin{array}{l}\text { Within } \\
\text { Groups }\end{array}$ & 20000 & 22 & 909.0910193 & & & \\
\hline
\end{tabular}

Total $\quad 34932.58 \quad 23$

Tabel 3 : Uji One-way Anova dosis perlakuan dengan kadar zat $\mathrm{Pb}$ di plasma darah mencit

Uji one-way Anova menunjukkan nilai $P$ sebesar 0.000530178 sehingga terdapat perbedaan bermakna kadar $\mathrm{Pb}$ plasma darah mencit berdasarkan besar dosis perlakuan. Nilai $P<0.05$ mendukung hipotesis bahwa terdapat pengaruh besarnya dosis konsumsi zat $\mathrm{Pb}$ terhadap akumulasi zat $\mathrm{Pb}$ di dalam plasma darah mencit

\section{Pembahasan}

Perlakuan yang diberikan terhadap mencit merupakan model toksikokinetik yang dapat terjadi pada manusia. Dosis perlakuan dibagi menjadi dua tingkat, dosis sedang (50 ppm) dan dosis tinggi (100ppm).(Giddabasappa,2011) Pemberian dosis melalui air minum yang telah dicampur dengan zat $\mathrm{Pb}$ acetate sehingga memiliki konsentrasi sesuai dengan yang diinginkan. Mencit tidak diberikan air minum selain air minum tersebut.

Kadar zat $\mathrm{Pb}$ dalam plasma darah mencit terjadi peningkatan sesuai dengan bertambahnya dosis zat $\mathrm{Pb}$ yang terkandung dalam air minum. Namun kelompok kontrol yang hanya diberi air minum kran tanpa dicampuri zat $\mathrm{Pb}$ ternyata menunjukkan akumulasi zat $\mathrm{Pb}$ di dalam plasma darahnya walaupun dalam kadar rendah.

Kadar zat $\mathrm{Pb}$ pada plasma darah mencit yang mendapatkan perlakuan adalah $0.11 \mathrm{mg} / \mathrm{L}$ sampai $0.14 \mathrm{mg} / \mathrm{L}$. sebenarnya tidak ada batas normal kadar $\mathrm{Pb}$ di dalam plasma bagi manusia. Namun kadar $\mathrm{Pb}$ plasma darah diatas $0.10 \mathrm{mg} / \mathrm{L}$ sudah dianggap toksik dan memiliki efek merusak pada tubuh manusia. Negara-negara maju telah menetapkan kadar maksimal zat $\mathrm{Pb}$ di dalam darah pada batas $0,1 \mathrm{mg} / \mathrm{L}$ untuk anakanak dan 0,15 mg/L untuk dewasa. (CDC, 2000)

Anak-anak merupakan kelompok yang paling sensitif terhadap toksisitas $\mathrm{Pb}$. Anak-anak melakukan absorbsi / penyerapan $\mathrm{Pb}$ lebih besar jika dibandingkan dewasa. Selain itu masa pertumbuhan organ-organ pada anak-anak juga membuat anak-anak lebih rentan dibandingkan dewasa. Kadar plasma zat $\mathrm{Pb}$ sebesar $0,1 \mathrm{mg} / \mathrm{L}$ sudah memiliki pengaruh terhadap kecerdasan, CDC (Centerf for Disease Control) di Amerika serikat mengatakan bahwa tidak adanya penurunan kadar plasma $\mathrm{Pb}$ pada batas $0,1 \mathrm{mg} / \mathrm{L}$ dalam waktu lama akan menurunkan IQ sebesar 2,5 poin. Jika kadar $\mathrm{Pb}$ di dalam plasma mencapai $0,8 \mathrm{mg} / \mathrm{L}$ maka akan merusak berbagai macam organ termasuk ginjal.(UNEP, 1997)

Toksisitas zat $\mathrm{Pb}$ dapat terjadi akibat masuknya zat $\mathrm{Pb}$ ke dalam tubuh manusia. Absorbsi bisa melalui konsumsi air per oral serta udara yang dihirup. Penelitian ini menggunakan model absorbsi berupa air minum. WHO telah menetapkan batas toksik air yang mengandung $\mathrm{Pb}$ pada nilai $10 \mu \mathrm{g} / \mathrm{L}$. (UNEP, 1997)

\section{Daftar Pustaka}

Albalak Rachel, Noonan Gary, Buchanan Sharunda et al. (2003) Blood lead levels and risk factors for lead poisoning among children in Jakarta,Indonesia. The Science of The Total Environment 301(1-3) : 75-85

Barbossa Fernando, Tanus-santos Jose Eduardo, Gerlach Raquel Fernanda et al. (2005) A critical review of biomarkers used for monitoring human exposure to lead : Advantage, limitation and future need. Environtmental Health Prespective 113(12) :1669-1674

Browne DR, Husni A, Risk MJ (1999) Airborne lead and particulate levels in Semarang Indonesia and potential health impacts.The Science of the Total Environment (227) : 145- 154

Chahaya S Indra, Dharma Surya, Simanullang Lenni (2005) Kadar Timbal (Pb) dalam specimen darah tukang becak mesin di kota Pematang Siantar dan beberapa faktor yang berhubungan. Majalah Kedokteran Nusantara 38(03) : 223-229

Giddabasappa A., Hamilton Ryan W., Chaney S. (2011) Low-Level Gestational Lead Exposure Increases Retinal Progenitor Cell Proliferation and Rod Photoreceptor and 
Bipolar Cell Neurogenesis in Mice. Environmental Health Perspectives 119(1): 71-77

Heinze et al (1998) Assessment of lead exposure in schoolchildren from Jakarta http://ehp.niehs.nih.gov/members/1998/106 p499-501heinze/heinze-full.html

Komousani Taha A, Mouselhy Said S (2011) Modulation of lead biohazards using a combination of epicatechin and lycopene in rats. Human and Experimental Toxicology 30(10) 1674-1681

Kurniawan Wahyu (2008) Hubungan kadar $\mathrm{Pb}$ dalam darah dengan profil darah pada mekanik kendaraan bermotor. Program Pascasarjana Universitas Diponegoro Semarang

Ma Yushui, Fu Da, Liu Zongping (2012) Effect of lead on apoptosis in cultured rat primary osteoblast. Toxicology and Industrial Health 28(2) : 136-146.

Misrha KP, Chauhan UK, NaikSita (2006) Effect of lead exposure on serum immunoglobulins and reactive nitrogen and oxygen intermediate. Human and Experimental Toxicology 25 :661-665

CDC. (2000). Eliminating Childhood Lead Poisoning: A Federal Strategy Targeting Lead Paint Hazards. President's Task Force on Environmental Health Risks and Safety Risks to Children. http://www.cdc.gov/nceh/lead/about/progra m.htm

Sakkir B, Khidri, M.A, Sjafruddin Ahmad (2008) Kadar timbal dalam darah pada anak-anak di kotaMakasar. Jurnal Kesehatan Masyarakat Madani 01(02)

Wang Lin, Wang Zengyong, Liu Jianzhu (2010) Protective effect of $\mathrm{N}$-acetilcysteine on experimental chronic lead nephrpotoxicity in immature female rats. Human and Experimental Toxicology 29(7) : 581-591

UNEP. (1997). Global Oportunities for Reducing the Use of Leaded Gasoline. http://www.chem.unep.ch/pops/pdf/lead/toc. htm 